\title{
Removal of Copper (II) and Zinc (II) ions from Aqueous Solution by Biosorption onto Aminated Tea Waste
}

\author{
Bindra Shrestha ${ }^{*}$, P.L. Homagai, M.R. Pokhrel, K.N. Ghimire \\ Central Department of Chemistry, Tribhuvan University, Kirtipur, Nepal \\ E-mail:binraghu@yahoo.com.
}

\begin{abstract}
An efficient and cost effective non-conventional biosorbent has been prepared from tea waste by amination with ethylenediamine. The prepared adsorbent, ATW was characterized using elemental analysis, scanning electron microscopic image and FTIR spectroscopy. Its adsorption behavior for $\mathrm{Cu}^{++}$ and $\mathrm{Zn}^{++}$ions was studied by using batch adsorption method. The maximum adsorption capacity onto ATW was found to be $46.4 \mathrm{mg} / \mathrm{g}$ and $30.08 \mathrm{mg} / \mathrm{g}$ for $\mathrm{Cu}^{++}$and $\mathrm{Zn}^{++}$respectively. The effect of $\mathrm{pH}$ of solution, initial metal concentration and contact time for removal of metal ions were studied. The applicability of data was analyzed by Langmuir isotherm. The kinetics of removal of $\mathrm{Cu}^{++}$and $\mathrm{Zn}^{++}$ions was studied using pseudosecond order model, in which the data were well fitted.
\end{abstract}

Keywords: Tea waste, biosorbent, amination, Langmuir isotherm, heavy metals.

\section{Introduction}

Heavy metals like copper and zinc are essential elements for the living beings. However they become toxic at higher concentrations ${ }^{1}$. The extensive use of these metals in various industries have discharged large amount of these metals into the environment. The conventional methods to remove these metals from the industrial waste water are precipitation, coagulation, solvent extraction, adsorption and ion exchange $^{2}$. At low concentration, metal removal is more efficient by ion exchange and activated carbon ${ }^{3}$ but they are expensive. The use of low cost and ecofriendly chemically modified agricultural waste of biological origin may be an economic solution to this problem.

The consumed tea leaves are discharged as waste material-tea waste (TW). The TW vitally contains lignin, cellulose and hemicelluloses. These natural polymers have been reported having excellent metal binding capacity. So TW can be used as an adsorbent for removal of heavy metals from aqueous solution. Islam, et.al. used tea waste to remove $\mathrm{Pb}^{++}$ions and Mahvi, et.al. used it for sequester of $\mathrm{Cd}^{++}$and $\mathrm{Pb}^{++}$ from their aqueous solution ${ }^{4,5}$. The present study is focused to investigate the capability of TW for removal of $\mathrm{Cu}^{++}$and $\mathrm{Zn}^{++}$from their aqueous solution ${ }^{6-10}$.

To enhance the metal binding capacity TW can be chemically modified by introducing an amino group ${ }^{11.12}$. The Nitrogen of amino group as a soft ligand increases the uptake capacity for metals like $\mathrm{Cu}^{++}$ and $\mathrm{Zn}^{++}$, which are classified as soft acids. Thus for the potential application of the TW, it is chemically modified by introducing amino group and the aminated tea waste (ATW) is developed as a low cost, simple and efficient biosorbent.

\section{"Corresponding author}


J. Nepal Chem. Soc., vol. 28, 2011

\section{Experimental Methods}

\section{Preparation of biosorbent}

$50 \mathrm{~g}$ of tea waste was thoroughly washed with boiling water and dried in oven at $80^{\circ} \mathrm{C}$.The dried mass was treated with concentrated $\mathrm{H}_{2} \mathrm{SO}_{4}$ and it was washed with distilled water till the filtrate became neutral and dried in oven. The charred sample was mixed with thionylchloride $\left(\mathrm{SOCl}_{2}\right)$ in presence of pyridine maintaining the temperature at $0^{\circ} \mathrm{C}$. The mixture was then heated at $70^{\circ} \mathrm{C}$ for $2 \mathrm{~h}$. The mixture was cooled and remaining $\mathrm{SOCl}_{2}$ was decomposed with ice and filtered. The sample was then washed with distilled water followed by propanol and dried. The chlorinated sample was mixed with dimethylsulphoxide (DMSO), sodium carbonate and ethylenediamine and then heated at $70^{\circ} \mathrm{C}$ for $6 \mathrm{~h}$. The mixture was cooled, filtered and washed with $0.1 \mathrm{M} \mathrm{HCl}$. The material was then washed with distilled water till neutrality. Finally it was washed with propanol and dried in an oven at $70^{\circ} \mathrm{C}$ for $24 \mathrm{~h}$ it is called as aminatedtea waste (ATW)

The stock solution of $\mathrm{Cu}^{++}$and $\mathrm{Zn}^{++}(1000 \mathrm{mg} / \mathrm{L})$ was prepared by dissolving calculated amount of $\mathrm{CuSO}_{4} .5 \mathrm{H}_{2} \mathrm{O}$ and $\mathrm{ZnSO}_{4} .7 \mathrm{H}_{2} \mathrm{O}$ in $0.1 \mathrm{M} \mathrm{HNO}_{3}$. Then working solutions of required concentrationswere prepared from the stock solution. During the experiment, $\mathrm{pH}$ of the solution was maintained using nitric acid and sodium hydroxide solution and 2-[4-(2-hydroxymethyl)-1-piperazinyl]ethanesulfonic acid [HEPES] was used as buffer. All the chemicals used were of AR grade and double distilled water was used for the experimental work.

Adsorption experiments were studied using batch equilibrium experiment. The experiments were performed at $25^{\circ} \mathrm{C}$ using $20 \mathrm{ml}$ metal solution and $25 \mathrm{mg}$ of adsorbent. The reaction mixtures were shaken in a mechanical shaker for $24 \mathrm{~h}$ at $150 \mathrm{rpm}$. The optimized adsorption parameters were contact time, initial concentration and $\mathrm{pH}$ of the solution. After adsorption the solutions were filtered and were analyzed for metal ions concentration using atomic absorption spectroscopy (Chemito AA 202, AAS).

\section{Results and Discussion}

\section{Characterization}

The surface morphology of TW and ATW were studied by SEM image. Fig.1a and 1b show the SEM of TW and ATW, respectively, in which the surface morphology has been changed after amination. It confirmed the chemical modification of the surface of the adsorbent. The SEM of ATW showed apparently isolated and irregularly distributed pores, which are supposed to be formed due to the increase of effective diffusion surface area derived from pore formation. It facilitates the adsorption of metal ions ${ }^{13,14}$. The FTIR spectrum of the surface of TW and ATW are shown in Fig. 2. The broad and intense peaks around $3380 \mathrm{~cm}^{-1}$ in the spectrum of TW correspond to O-H stretching vibration. It indicates the free $\mathrm{O}-\mathrm{H}$ group on the surface of the adsorbent and confirms the presence of alcohols and polyphenols in cellulose and lignin. The peak observed at $2923 \mathrm{~cm}^{-1}$ corresponds to C-H stretching and the peak around $1647 \mathrm{~cm}^{-1}$ is due to $\mathrm{C}=\mathrm{O}$ group. The broad band around $600 \mathrm{~cm}^{-1}$ can be assigned to bending mode of aromatic compounds ${ }^{15}$.

In ATW the broad strong band ranging from $3085-3653 \mathrm{~cm}^{-1}$ may be due to overlapping of O-H and $\mathrm{N}-\mathrm{H}$ stretching. Similarly the peaks at 1433 and $1094 \mathrm{~cm}^{-1}$ are due to C-H bending and C-N stretching respectively. It indicates the introduction of amino group in ATW. The percentage of Nitrogen is 3.43 in TW, which was changed to 9.52 in ATW, confirmed the amination on ATW. 

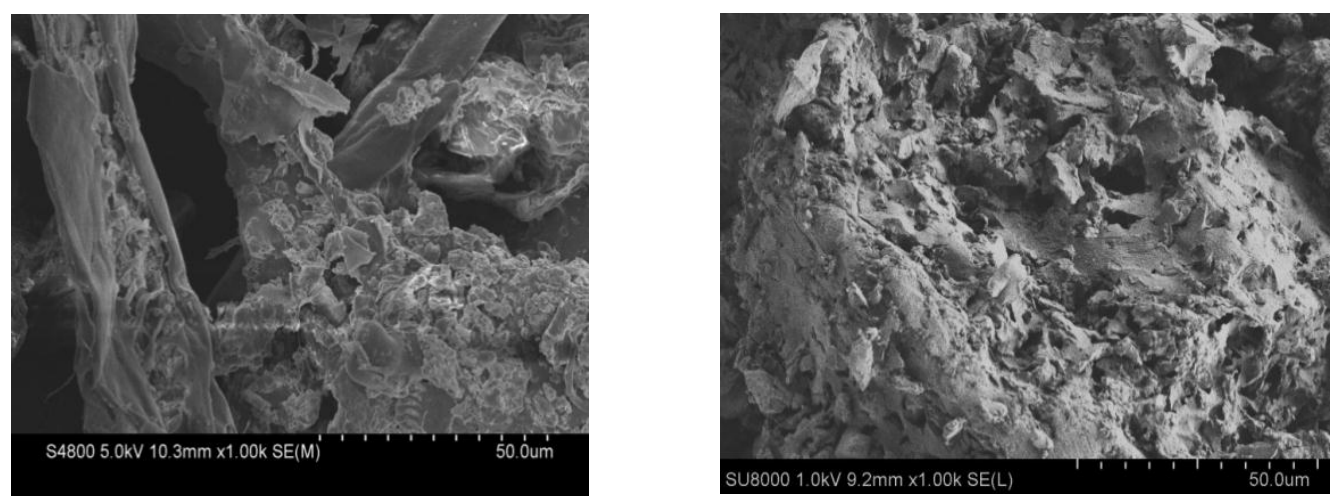

Figure 1: la (left) SEM image of TW and $1 b$ (right) SEM image of ATW

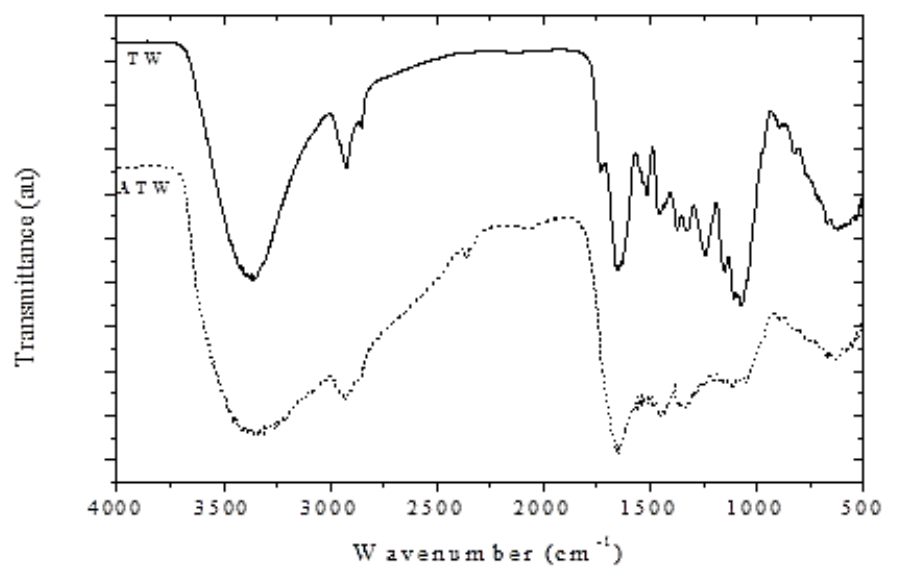

Figure 2: FTIR spectrum of Tea Waste (TW) and Aminated Tea Waste (ATW)

\section{Adsorption equilibrium}

The effect of $\mathrm{pH}$ on the adsorption of $\mathrm{Cu}^{++}$and $\mathrm{Zn}^{++}$is shown in Fig. 3. As shown in the plot the adsorption capacity increases with increasing $\mathrm{pH}$ of the solution and maximum adsorption was obtained at $\mathrm{pH} 5$ and $\mathrm{pH} 6$ for $\mathrm{Cu}^{++}$and $\mathrm{Zn}^{++}$, respectively. The effect of $\mathrm{pH}$ can be explained considering the surface charge on the adsorbent. At low $\mathrm{pH}$, there is a competition between the metal ions and $\mathrm{H}^{+}$ions for binding sites on the surface of the adsorbent. So adsorption of metal ions was low due to high positive charge density of protons on the surface sites. At high $\mathrm{pH}$, positive charge density on the adsorbent surface decreases which results in decrease in electrostatic repulsion and increase the metal ion adsorption to reach optimum value. 
The adsorption efficiency (A\%) and amount of metal adsorbed was calculated by using equation (1) and (2), respectively

$$
\begin{aligned}
& \mathrm{A} \%=\frac{C_{i}-C_{e}}{C_{i}} X 100 \\
& \mathrm{q}_{\mathrm{e}}=\frac{C_{i-} C_{e}}{W} X \frac{V}{1000}
\end{aligned}
$$

where $\mathrm{q}_{\mathrm{e}}$ is amount of metal adsorbed per unit mass of adsorbent $(\mathrm{mg} / \mathrm{g})$ at equilibrium time, $\mathrm{V}$ is volume of metal solution $(\mathrm{ml}), \mathrm{W}$ is mass of adsorbent $(\mathrm{g}), \mathrm{C}_{\mathrm{i}}$ and $\mathrm{C}_{\mathrm{e}}$ are concentration of metal ions at initial and at equilibrium time, respectively.

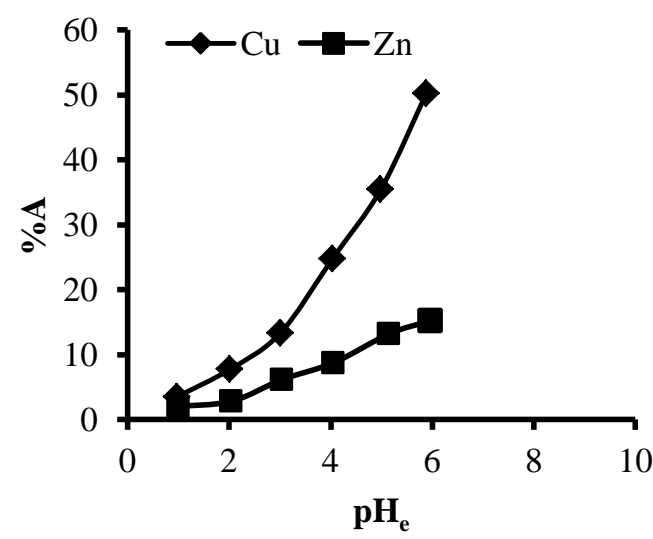

Figure 3: Effect of $\mathrm{pH}$ on adsorption of $\mathrm{Cu}^{++}$and $\mathrm{Zn}^{++}$onto $\mathrm{ATW}$

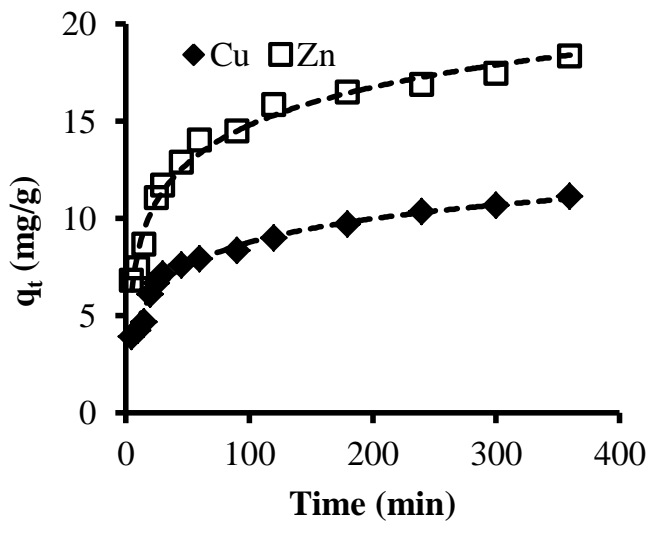

Figure 4: Adsorption kinetics of $\mathrm{Cu}^{++}$and $\mathrm{Zn}^{++}$ onto ATW

The result of time dependency for the adsorption of $\mathrm{Cu}^{++}$and $\mathrm{Zn}^{++}$onto ATW is shown in Fig. 4. The equilibrium time was found around 150-160 minutes.

A plot of adsorption isotherm for $\mathrm{Cu}^{++}$and $\mathrm{Zn}^{++}$onto ATW is given in Fig.5. In isotherm, it appears that adsorption of metal ions increases with the increase of metal ion concentrations. The adsorption is eventually limited at equilibrium due to the presence of fixed number of active sites on the surface of adsorbent and results a plateau on the isotherm curve. It suggests that adsorption is according to Langmuir adsorption model. The linear form of the Langmuir model is given in equation (3)

$$
\frac{C_{e}}{q_{e}}=\frac{1}{b q_{m}}+\frac{C_{e}}{q_{m}}
$$

where, $\mathrm{C}_{\mathrm{e}}(\mathrm{mg} / \mathrm{L})$ is the concentration of metal ions after adsorption, $\mathrm{q}_{\mathrm{e}}(\mathrm{mg} / \mathrm{g})$ is the amount of metal ions adsorbed per gram of adsorbent, $\mathrm{b}(\mathrm{L} / \mathrm{mg})$ is binding constant and $\mathrm{q}_{\mathrm{m}}$ is the maximum adsorption capacity. The metal ions adsorption onto ATW gives linear relationship with Langmuir isotherm which is shown in Fig.6. The parameters calculated from the Langmuir plot and experimental $\mathrm{q}_{\max }$ are given in Table 1. The maximum adsorption capacity of ATW for $\mathrm{Cu}^{++}$and $\mathrm{Zn}^{++}$ions adsorption are found to be 46.4 and $30.08 \mathrm{mg} / \mathrm{g}$, respectively. 
Kinetics for adsorption of metal ions onto ATW was studied using pseudo second order kinetic model as shown in Fig.7. It assumes that the rate is proportional to the square of the number of remaining free surface sites. In linearized form it can be expressed as in equation 4.

$$
\frac{t}{q_{t}}=\frac{1}{K_{2} q_{e}^{2}}+\frac{t}{q_{e}}
$$

where, qt is the amount of adsorption at time $\mathrm{t}(\mathrm{min}), \mathrm{K}_{2}(\mathrm{~g} / \mathrm{mg} / \mathrm{min})$ is the rate constant of the pseudo second order kinetic adsorption. The pseudo second order kinetic plot of $t / q_{t}(\min g / m g)$ verses $t$ (min) gave a straight line with high correlation coefficient value of about unity, indicating that the adsorption of $\mathrm{Cu}^{++}$and $\mathrm{Zn}^{++}$ions onto ATW proceeded by pseudo second order kinetic model. The values of rate constant and correlation coefficient constants for the model are given in Table 2.

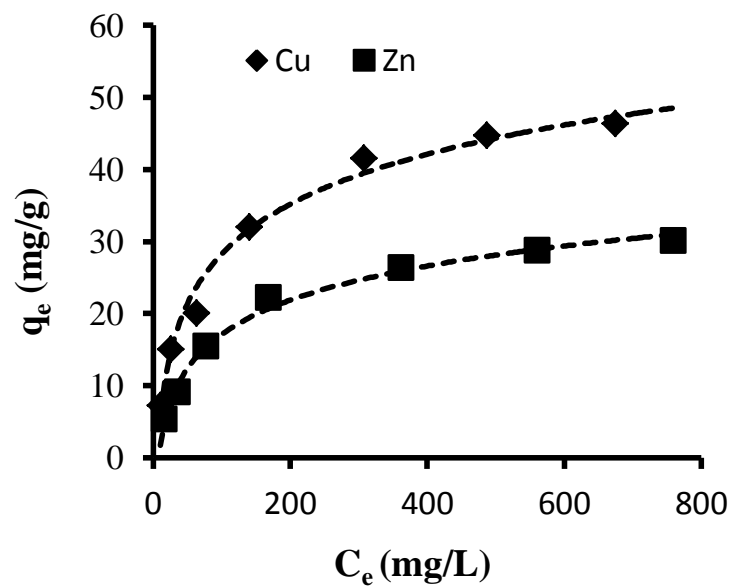

Figure 5: Adsorption isotherm for adsorption of $\mathrm{Cu}^{++}$and $\mathrm{Zn}^{++}$onto $\mathrm{ATW}$

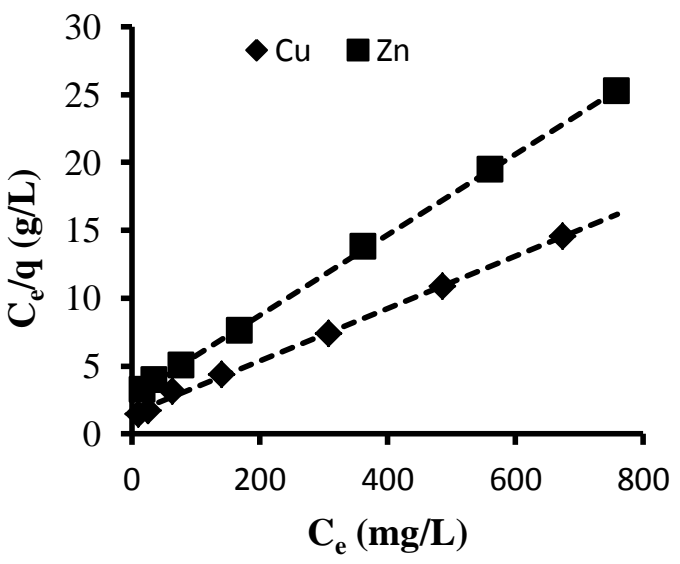

Figure 6: Langmuir plot for the adsorption of $\mathrm{Cu}^{++}$and $\mathrm{Zn}^{++}$onto $\mathrm{ATW}$

Table 1: Langmuir adsorption isotherm model parameters and experimental $q_{\max }$

\begin{tabular}{|c|c|l|l|c|}
\hline Metal ions & $\mathrm{q}_{\mathrm{m}}$ (expt.) & $\mathrm{q}_{\mathrm{m}}($ graph $)$ & $\mathrm{b}(\mathrm{L} / \mathrm{mg})$ & $\mathrm{R}^{2}$ \\
\hline $\mathrm{Cu}^{++}$ & 46.4 & 51.81 & 0.01286 & 0.9975 \\
\hline $\mathrm{Zn}^{++}$ & 30.08 & 33.67 & 0.010623 & 0.9998 \\
\hline
\end{tabular}

Table 2: Sorption kinetics of pseudo second order model for $\mathrm{Cu}^{++}$and $\mathrm{Zn}^{++}$adsorption onto ATW

\begin{tabular}{|c|c|c|}
\hline Metal ions & $\mathrm{K}_{2}(\mathrm{~g} / \mathrm{mg} / \mathrm{min})$ & $\mathrm{R}^{2}$ \\
\hline $\mathrm{Cu}$ & 0.0041 & 0.995 \\
\hline $\mathrm{Zn}$ & 0.0029 & 0.997 \\
\hline
\end{tabular}




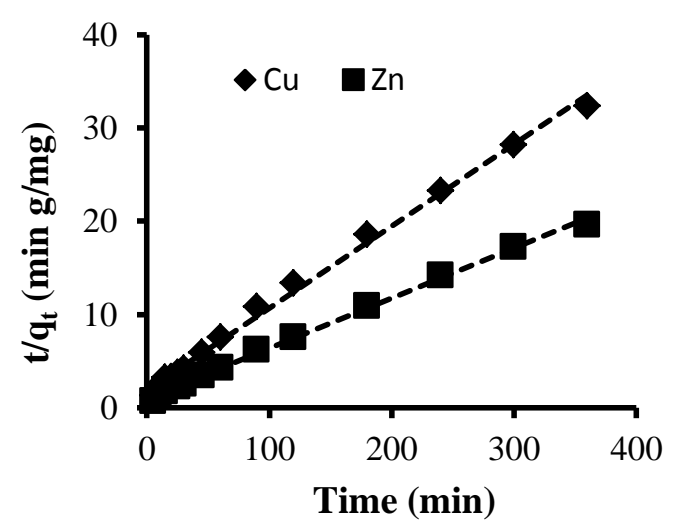

Figure 7: Pseudo-second order plot for adsorption of $\mathrm{Cu}^{++}$and $\mathrm{Zn}^{++}$onto ATW.

\section{Conclusions}

ATW can be used as an efficient and eco-friendly biosorbents for the removal of $\mathrm{Cu}^{++}$and $\mathrm{Zn}^{++}$from this study. The sorption capacity of the adsorbent depends upon the $\mathrm{pH}$ of the solution, concentration of metal ions and contact time. The results of adsorption experiment are in good agreement with Langmuir adsorption isotherm. The maximum uptake of $\mathrm{Cu}^{++}$and $\mathrm{Zn}^{++}$are 46.4 and $30.08 \mathrm{mg} / \mathrm{g}$, respectively from the isotherm studies. Hence the adsorbent can be potentially used for removal of $\mathrm{Cu}^{++}$and $\mathrm{Zn}^{++}$from their aqueous solutions.

\section{Acknowledgements}

We would like to thank National Academy of Science and Technology (NAST) Nepal, for providing $\mathrm{Ph}$.D. Scholarship to one of the researchers and we acknowledge Dr. A.P. Yadav, Central Department of Chemistry for SEM images.

\section{References}

1. P.L. Homagai, K.N. Ghimire, K. Inoue, Separation Sci. Technol, 2011, 46, 1-10.

2. H.K. An, B.Y. Park, D.S.Kim, Water Res., 2001, 35, 3551-3556.

3. B. Volesky. Z.R. Holan, Biotechnol. Progress, 1995, 11, 235-250.

4. T.S.A. Islam, H.A. Begum, M.A. Hossain, M.T. Rahman, J. Bangladesh Acad. of Sci., 2009, 33 (2), 167-178.

5. A.H. Mahvi, D. Naghipour, F. Vaezi, S. Nazmara, American J. Applied Sci., 2005, 2, 372-375.

6. H. Cho, D. Oh, K. Kim, J.Hazardous Material., 2005, B 127, 187-195.

7. F. Pagnanelli, A. Esposito, L. Toro, F. Veglio, Water Research, 2003, 37, 627-633.

8. W.S. WanNgah, M.A.K.M. Hanafiah, Bioresource Technol., 2008, 99, 3935-3948.

9. M. Thirumavalavan, Y.L. Lai, L.C. Lin, J.F. Lee, J. Chem. Eng. Data, 2010, 55, 1186-1192.

10. A.W. Krowiak, R.G. Szafran, S. Modellski, Desalination, 2011, 265, 126-134.

11. K.N. Ghimire, K. Inoue, K. Makino, T. Miyajima, Sep. Sci. Technol., 2002, 37, 2785.

12. P.L. Homagai, D. Bashyal, H. Poudyal, K.N. Ghimire, J. Nepal Chem. Soc., 2006, 26, 53-60.

13. N. Sankararamakrishnan, R. Sanghi,, Carbohydrate Polymers, 2006, 66, 160-167.

14. V.M. Nurchi, I. Villaescusa, Coordination Chemistry Reviews, 2008, 252, 1178-1188.

15. R.L. Shriner, C.K.F. Hermann, T.C. Morill, D.Y. Curtin, R.C. Fuson, The Systematic Identification of Organic compounds, Seventh ed. Wiley, New York, 1998. 